\title{
Dynamics of an estuarine nursery ground: the spatio-temporal relationship between the river flow and the food web of the juvenile common sole (Solea solea, L.) as revealed by stable isotopes analysis
}

\author{
C. Kostecki ${ }^{a,{ }^{*}}$, F. Le Loc'h ${ }^{b}$, J.-M. Roussel ${ }^{c}$, N. Desroy ${ }^{d}$, D. Huteau ${ }^{c}$, P. Riera ${ }^{\mathrm{e}}$, H. Le Bris ${ }^{\mathrm{a}}$ and O. Le \\ Pape $^{\mathrm{a}}$
}

\begin{abstract}
a Université Européenne de Bretagne, UMR 985 Agrocampus Ouest, Inra «Ecologie \& Santé des Ecosystèmes», Ecologie halieutique, Agrocampus Rennes, 65 rue de St Brieuc, CS 84215, 35042 Rennes, France

${ }^{\mathrm{b}} \mathrm{CRH}, \mathrm{UMR} 212 \mathrm{EME}, \mathrm{IRD}$, Avenue Jean Monnet, 34200 Sète, France

c INRA, UMR 985 « Ecologie \& Santé des Ecosystèmes », Ecologie aquatique et Préservation des Espèces et Habitats aquatiques, 65 rue de St Brieuc, 35042 Rennes, France

d IFREMER, Laboratoire environnement - ressources Finistère-Bretagne Nord, CRESCO, 38 rue du Port Blanc, BP 80108, 35801 Dinard Cedex, France

e UPMC, Univ Paris 6, UMR 7144 CNRS, Adaptation et Diversité en Milieu Marin, Station Biologique de Roscoff, Place Georges Teissier, BP74, 29682 Roscoff Cedex, France
\end{abstract}

*: Corresponding author : C. Kostecki, email address : caroline.kostecki@agrocampus-ouest.fr

\begin{abstract}
:
Estuaries are essential fish habitats because they provide nursery grounds for a number of marine species. Previous studies in the Bay of Vilaine (part of the Bay of Biscay, France) have underlined the estuarine dependence of juvenile common sole (Solea solea, L.) and shown that the extent of sole nursery grounds was positively influenced by the variability of the river flow. In the present study, stable carbon and nitrogen isotopes were used to describe the trophic network until the young-of-theyear sole and to compare interannual variations in the dominant trophic pathways in the sole nursery areas in this bay. Particulate organic matter (POM), sediment organic matter (SOM), microphytobenthos, benthic invertebrate sole prey and young-of-the-year common sole were collected during the summer over 4 years characterised by contrasting river discharges. POM isotopic signatures were used to identify the origins of nutrient and organic matter assimilated into the estuarine food web through benthic organisms to juvenile common sole. Interannual spatial variations were found in the POM carbon stable isotope signatures, with the importance of these variations depending on the interannual fluctuations of the river flow. Moreover, the spatio-temporal variability of this POM isotopic signature was propagated along the food webs up to juvenile sole, confirming the central role of river discharge and terrigeneous subsidy input in the estuarine benthic food web in determining the size of the sole nursery habitat.
\end{abstract}

Keywords: Juvenile Common Sole; Stable Isotopes; Estuarine Nursery Grounds; Food Web; Eastern Atlantic 


\section{Introduction}

Coastal and estuarine systems are highly productive environments. They are essential fish habitats as they play the role of nursery grounds for many marine species that are widely distributed on the continental shelf (Beck et al., 2001; Peterson, 2003), particularly flatfish (Van der Veer et al., 2000). Hence, the available coastal and estuarine habitats and their quality have a considerable influence on recruitment levels (Rijnsdorp et al., 1992; Gibson, 1994). Human pressure is especially high in these areas, and the natural communities may be threatened. Because juveniles are confined within these coastal and estuarine habitats, recruitment levels and population size can be affected by habitat loss and nutrient and contaminant loading (Johnson et al., 1998; Peterson et al., 2000; Le Pape et al., 2007). It is thus crucial not only to protect these vulnerable habitats, but also to better understand their functioning and to determine optimal habitats in order to support decision-making concerning their management (Rubec et al., 1999; Beck et al., 2001).

Inshore waters of the Bay of Biscay (west coast of France) support nursery areas for several marine species, particularly the common sole Solea solea (L., 1758; Dorel et al., 1991). In this site, young-of-the-year (YoY) sole are more abundant in shallow, soft-bottom areas of the estuarine and semi-enclosed sectors of the coast (Le Pape et al., 2003b). In the Bay of Vilaine, an estuarine nursery of the Bay of Biscay, the extent of the nursery grounds and the related young sole abundance have also been shown to be influenced by the variability of the river flow in winter and spring, both before and during young sole settlement (Le Pape et al., 2003c). A link between river flow and fish recruitment has also been observed for sole in the Rhone estuary, France (Salen-Picard et al., 2002) and for other fish species in estuaries all over the world (Quiñones and Montes, 2001; Kimmerer, 2002; Staunton-Smith et al. 2004; Rowell et al., 2005). It is assumed that the river flow facilitates the immigration of young fish stages by favouring the development of benthic invertebrates, which are suitable food for young fish (Gibson, 1994). However, the ecological processes implied in this link between river flow and recruitment are still largely unknown.

One way to improve our knowledge about the relationship between river flow, benthic invertebrates and juvenile common sole is to employ trophic tracers, such as stable isotopes. Trophic tracers constitute a powerful tool for ecological studies, allowing nutrient pathways and energy sources to be differentiated, as well as food web interactions and changes in trophic position to be better understood (Peterson and Fry, 1987). Stable isotopes of nitrogen $\left(\delta^{15} \mathrm{~N}\right)$ are often used in ecological studies to assess trophic levels, while stable isotopes of carbon $\left(\delta^{13} \mathrm{C}\right)$ are used to distinguish production sources (DeNiro and Epstein, 1981; Minagawa and Wada, 1984; Fry, 2006). Compared with marine primary producers, terrestrial producers are significantly ${ }^{13} \mathrm{C}$-depleted, and particulate organic matter (POM) from both origins can be differentiated by using stable isotopes of carbon (Vander Zanden and Rasmussen, 2001; Yokoyama and Ishihi, 2007). On the one hand, the transfer of terrestrial POM into benthic food webs (Peterson et al., 1985; Riera et al., 1999; Bouillon et al., 2000; Salen-Picard and Arlhac, 2002; Choy et al., 2008; Zeug and Winemiller, 2008) and the transfers from the lower trophic levels to flatfish juveniles have already been investigated (Gaston et al., 2004; Winemiller et al. 2007). Using this methodological approach on benthic fish species in the Rhone, France (Darnaude et al. 2004; Darnaude, 2005), the Tagus, Portugal (Vinagre et al., 2008) and the Thames, UK (Leakey et al., 2008), benthic food webs have been shown to depend on freshwater nutrient and organic matter inputs. On the other hand, the extent of the river plume influences the size of the nursery habitat and the number of juveniles produced in the Bay of Vilaine (Le Pape et al. 2003c).

The main objective of this study was thus to trace the terrestrial inputs in the trophic network of juvenile sole in the Vilaine Bay and to analyse the spatio-temporal variations of the food sources assimilated by young flatfish in terms of the interannual variations of the river flow. 


\section{Materials and methods}

\subsection{Vilaine estuary situation and sampling}

The Vilaine estuary is located on a shallow coastal inlet of the northern Bay of Biscay (Fig. 1). In this estuary, the tide is blocked by a dam located $10 \mathrm{~km}$ upstream of the river mouth. The flow of the Vilaine River varies greatly depending on rainfall, with considerable seasonal and interannual fluctuations (Le Pape et al., 2003d). The Vilaine estuary shelters important nursery grounds for the common sole within the Bay of Biscay (Koutsikopoulos et al., 1989).

Four sampling surveys were undertaken in mid-July 2004, 2005, 2007 and 2008, just after the YoY sole finished colonizing the estuary (Marchand, 1991). Mid-July is a representative sampling period for assessing YoY sole distribution because during their first summer, juvenile sole have a very low mobility, and thus their distribution pattern remains relatively constant (Dorel et al., 1991). These four annual surveys correspond to contrasting river discharge scenarios (Fig. 2). From February to June (i.e., before and during the young sole settlement in the Vilaine estuary; Le Pape et al., 2003cd), the river discharge averaged $66 \mathrm{~m}^{3} . \mathrm{s}^{-1}$ and $25 \mathrm{~m}^{3} . \mathrm{s}^{-}$ ${ }^{1}$ in 2004 and 2005 respectively; thus these years can be considered as dry. Conversely, 2007 and 2008 were rainy years, and the river flow averaged $115 \mathrm{~m}^{3} \cdot \mathrm{s}^{-1}$ and $123 \mathrm{~m}^{3} \cdot \mathrm{s}^{-1}$, respectively, during the same period.

These surveys were done in similar neap tide conditions. Sampling areas were designated in order to collect YoY sole in two different areas of the study site (Fig. 1). Area A is located at the mouth of the Vilaine river, in the inner estuary just after the Arzal dam, and is greatly influenced by freshwater inflows. Area $B$ is in the external part of the estuary and benefits from the marine influence. These two locations were chosen based on previous knowledge of YoY sole distribution in this estuary (Dorel et al., 1991; Nicolas et al., 2007). They are always part of the nursery area, even during dry years when the extent of the nursery is limited (Le Pape et al., 2003c).

\subsection{Sample collection and preparation}

Juvenile sole were sampled in 2004, 2005, 2007 and 2008 in areas A and B. They were caught by a beam trawl, with a $2.9 \mathrm{~m}$ wide and $0.5 \mathrm{~m}$ high opening and a $10 \mathrm{~mm}$ stretched mesh net cod end. Hauls were carried out at 2.5 knots for 15 min, covering approximately $3400 \mathrm{~m}^{2}$ on average for each haul. Fourteen beam trawl hauls, distributed over the two study areas, were performed during the 4 surveys, allowing YoY sole to be caught (Table 1). For each haul, trawled sole were measured to estimate their age, and clearly identified YoY (i.e., total fish length under $11 \mathrm{~cm}$ ) were kept; at least 5 fish per sampling station (Table 1). All the samples were refrigerated on board during the survey, and once back in the laboratory stored at $-20^{\circ} \mathrm{C}$.

At the same sampling station, benthic fauna was simultaneously sampled with a Van Veen grab $\left(0.1 \mathrm{~m}^{2}\right)$ (Table 1). Grab samples were sieved, and benthic fauna was sorted and extracted from sediment particles. Organisms were identified to the lowest possible taxonomic level, generally to the species level.

Sediment samples were also collected with the Van Veen grab $\left(0.1 \mathrm{~m}^{2}\right)$ at the same sampling stations (Table 1). Sediment Organic Matter (SOM) was obtained by removing carbonates from sediment through acid washing $(1 \mathrm{M} \mathrm{HCl})$. The SOM samples were rinsed several times with distilled water and then dried $\left(60^{\circ} \mathrm{C}\right)$.

Water samples were collected just before the dam (Fig. 1), where there is no salinity intrusion (i.e., in freshwater) and in area A (Table 1). Particulate Organic Matter (POM) was obtained by filtering $1 \mathrm{I}$ of water over precombusted Whatman GF/F filters and then was stored at $-20{ }^{\circ} \mathrm{C}$. Subsequently, the filters were exposed to $\mathrm{HCl}$ vapor for $4 \mathrm{~h}$ in order to remove the carbonates, before being placed in tin cups.

Microphytobenthos (MPB) was sampled at low tide on the intertidal section of area $A$ and extracted using the method suggested by Riera and Richard (1996). Two hours after sampling, 
a $1 \mathrm{~cm}$ thick layer of the sediment was spread on flat trays in the laboratory. A nylon screen (63 $\mu \mathrm{m}$ mesh) was placed on the sediment surface and covered with a $5 \mathrm{~mm}$ thick layer of combusted silica powder (60 to $210 \mu \mathrm{m}$ ). The trays were exposed to light for 12 hours, and the silica powder was kept moist with filtered seawater from the sampling site. Then the top $2 \mathrm{~mm}$ of the silica powder, into which the motile microalgae had migrated, were gently scraped and sieved through a $63 \mu \mathrm{m}$ mesh to separate the microphytobenthos from the remaining silica powder. Microphytobenthos was finally collected on previously combusted Whatman GF/F filters, washed with $1 \mathrm{M} \mathrm{HCl}$, rinsed with Milli-Q water and freeze-dried. These filters were stored at $-20^{\circ} \mathrm{C}$.

\subsection{Stable isotopes}

\section{Sample preparation}

The benthic species selected for isotopic analysis were those that were dominant in terms of abundance and biomass and those that were potential prey for sole juveniles. In order to minimize the lipid effects on $\delta^{13} \mathrm{C}$ (Bodin et al., 2007), low-lipid muscle tissues were used for the mega- and macro-faunal samples (except polychaetes) used in the stable isotopes analysis. White muscle samples (Table 1) were taken from the dorsal sole musculature as recommended for fish (Pinnegar and Polunin 1999; Sweeting et al. 2007), from the abdomen of the Caridea and from the siphon of bivalves. Viscera, setae and the jaw were removed from large specimen of polychaetes by dissection, and the analyses were carried out on the remaining whole body (Le Loc'h and Hily, 2005). After dissection, the tissue samples from every taxon were washed with distilled water in order to prevent any contamination by sediment carbonates (Kharlmamenko et al., 2001; O'Reilly et al., 2002). All samples were frozen individually at $-20^{\circ} \mathrm{C}$ before freeze-drying. Each dried sample was then ground to obtain a homogeneous powder. Samples were weighed and encapsulated in a fold of tin before stable isotope analysis.

\section{Isotopic analysis}

The ${ }^{13} \mathrm{C} /{ }^{12} \mathrm{C}$ and ${ }^{15} \mathrm{~N} /{ }^{14} \mathrm{~N}$ ratios were determined by continuous-flow isotope ratio mass spectrometry (CF-IRMS). Samples were analysed using a Europa Scientific ANCA-NT 20-20 Stable Isotope Analyser, together with an ANCA-NT Solid/ Liquid Preparation Module (2004 2005) and a Finnigan Mat Delta XP isotope ratio mass spectrometer interfaced with a Carlo Erba NC2500 elemental analyzer (2007 - 2008).

As the samples contained more than $10 \%$ nitrogen, the CF-IRMS was operated in dual isotope mode, allowing $\delta^{13} \mathrm{C}$ and $\delta^{15} \mathrm{~N}$ to be measured in the same sample. Isotope ratios were reported in conventional delta $(\delta)$ notation as parts per mil (\%) relative to the international standard for Peedee Belemnite Carbonate (C) and atmospheric nitrogen (N). Repeat analyses of the IAEA and laboratory standards ( $\mathrm{N} 1, \mathrm{~N} 2, \mathrm{CH} 6, \mathrm{CH} 7$, acetalinide, cyclohexanone, nicotinamide and bovine liver) showed that maximum standard deviations for $\delta 13 \mathrm{C}$ and $\delta 15 \mathrm{~N}$ values were, respectively, 0.18 and $0.24 \%$. The standard deviations of the duplicate samples analysed averaged 0.18 and $0.48 \%$ for carbon and nitrogen. Single measurements were carried out; mean value and associated standard deviation were calculated on the replicated samples.

\subsection{Data analysis}

Dual $\delta^{13} \mathrm{C}-\delta^{15} \mathrm{~N}$ plots were used to present isotopic signatures of YoY sole Solea solea and potential $\mathrm{C}$ and $\mathrm{N}$ sources in the POM, SOM and MPB, and the benthic invertebrates (including Hydrobia ulvae, Macoma balthica, Cerastoderma edule, Nephtys hombergii and Crangon crangon) for the 2005 and 2007 surveys in area A. Associated standard deviation were plotted on this graph (points without error are related to single measure on sources). As the topic was 
here to focus on nursery function, the entire trophic network in area B and for other years are not presented; general patterns were indicated in the text.

In addition to this graphic analysis, thorough analysis were led on YoY sole. In that aim, error plots and associated Tukey multiple means comparisons were performed after verifying the application conditions. The aim was to test whether or not the C stable isotopic values in YoY soles followed temporal and/or spatial variations. All data for the 2 areas from all 4 years were compared. The first test focused on spatial variability: annual area $A$ and $B$ values were compared (area A versus area B). A second comparison was made to see whether there was any spatial variation within each year (e.g., area $A_{\text {Year } ;}$ versus area $B_{\text {Year } i,} i$ is included in $[2004,2005,2006,2008])$. Finally, a third comparison was made to investigate the interannual variation for both areas in all survey years (e.g., area $\mathrm{A}_{\text {Year i1 }}$ versus area $\mathrm{A}_{\text {Year i2 }}$ ).

\section{Results}

\subsection{YoY sole food web in the Vilaine estuary}

In 2005, particulate organic matter (POM) from freshwater was ${ }^{13} \mathrm{C}$-depleted and ${ }^{15} \mathrm{~N}$-enriched compared to POM from area A (Fig. 3 a). Sediment organic matter (SOM) was ${ }^{13} \mathrm{C}$-enriched compared with POM. Microphytobenthos (MPB) was the most ${ }^{13} \mathrm{C}$-enriched organic matter source compared to all other sources (SOM and POM) (Fig. 3a). Thus, the different freshwater and estuarine food sources (freshwater POM, estuarine POM and SOM, microphytobenthos only present on intertidal part of area $\mathrm{A}$ ) had distinct $\delta^{13} \mathrm{C}$ values and can be traced into the trophic network.

Differences in isotopic signatures were also found among benthic invertebrates (Fig. 3a). The bivalves facultative deposit feeder Macoma balthica and suspension feeder Cerastoderma edule had similar $\delta^{15} \mathrm{~N}$ values but differed in terms of their $\delta^{13} \mathrm{C}$ values, with $M$. balthica being more ${ }^{13} \mathrm{C}$-depleted than $\mathrm{C}$. edule (Fig. 3a). The small gastropod Hydrobia ulvae was ${ }^{13} \mathrm{C}$ - and ${ }^{15} \mathrm{~N}$ enriched compared to SOM and MPB. Both carnivorous taxa Nephtys hombergii and Crangon crangon had higher $\delta^{15} \mathrm{~N}$ signatures than the bivalves and gastropods. The $\mathrm{C}$ and $\mathrm{N}$ stable isotope signatures for the 0-group Solea solea were very close to Crangon crangon. As expected, we observed an increase in $\delta^{15} \mathrm{~N}$ for species occupying higher trophic positions in the food web.

In 2007, POM from freshwater and POM from area A were not different (Fig. 3b); SOM was still ${ }^{13} \mathrm{C}$-enriched compared with POM (Fig. 3b). Nevertheless, on the whole, the benthic food web in the nursery depicted by stable isotope analyses did not show a major divergence between sampling years (Fig. 3). In area A, interannual variations were mostly observed for POM, which was ${ }^{13} \mathrm{C}$-depleted in 2007 compared with 2005 (Fig. 3). Similarly, benthic invertebrates and YoY sole were ${ }^{13} \mathrm{C}$-depleted in 2007 compared to 2005, except for Cerastoderma edule. Moreover, we observed an increase in the variance for Macoma balthica, Crangon crangon and Solea solea in 2007 compared to 2005. General pattern was similar for the outer estuary and other years, with the same pattern for different groups but a different $\delta^{13} \mathrm{C}$ scale.

\subsection{Spatial and interannual variations in the isotopic values of YoY soles}

$\delta^{13} \mathrm{C}$ values of YoY soles in area $\mathrm{A}$ were statistically more depleted than signatures observed in area $B$, all years included (Fig. 4 and Table 2). More precisely, we found that YoY sole in area $A$ were significantly ${ }^{13} \mathrm{C}$-depleted compared to those in area B in 2007 and to a lesser extent in 2004, but not in 2005 nor in 2008.

We found no significant differences in the interannual variations of $\delta^{13} \mathrm{C}$ in area A between 2004 and 2005, but signatures were significantly higher during these two years than values obtained in 2007 and 2008 (Table 3a and Fig. 4). In area B, such interannual differences were mainly 
observed for 2008, which was significantly more depleted than 2004, 2005 and 2007 (Table 3b and Fig.4).

To sum up, we observed a clear gradient between the two study areas, represented by ${ }^{13} \mathrm{C}$ depletion being more accentuated inside the estuary. Moreover, the $\delta^{13} \mathrm{C}$ signatures in juvenile sole in 2007 and 2008 (wet years, Fig. 2) in area A were significantly depleted compared with 2004 and 2005 (dry years). The same tendency was observed in area B, but only for 2008 (Table 3 and Fig. 4).

\section{Discussion}

\subsection{The trophic structure of the nursery ground in Vilaine estuary}

In the present study, all samples were collected using a protocol comparable to previous studies of the trophic networks of juvenile common sole in estuarine nursery grounds (Darnaude et al., 2004; Leakey et al., 2008; Vinagre et al., 2008). Since isotopic fractionation levels vary among species (Hesslein et al. 1993, MacAvoy et al. 2001, Guelinckx et al., 2008), the present results cannot be used to provide a complete description of the trophic relationships in an estuarine nursery ground nor to determine accurate trophic levels for the different biological compartments of the food web. Nevertheless, our description of the structure of YoY sole food web in the Vilaine estuary allowed comparisons to be made with descriptions of other studied estuaries.

As in the Tagus estuary (Vinagre et al., 2008), analyzing the food web through its isotopic composition highlighted a clear scheme of interactions between the system components. The nitrogen signatures of organic matter sources, benthic invertebrates and juvenile common sole were different, and this isotopic gradient confirmed the species' trophic levels. There is also a clear difference in origin of organic matter in benthic food webs. Carbon sources can be distinguished through their $\delta^{13} \mathrm{C}$ values in relation to their terrestrial origins (Peterson et al., 1985; Riera and Richard, 1996; Riera et al., 1999; Bouillon et al., 2000; Yokoyama and Ishihi, 2007; Choy et al., 2008; Zeug and Winemiller, 2008), since freshwater particulate organic matter had lower values than marine POM. Thus, the large range of isotopic signatures measured in the present study allowed the assimilation and transfer of food sources to be traced through the YoY sole nursery food web.

The isotopic signatures of the two bivalve species, Cerastoderma edule and Macoma balthica, were slightly different, which can be explained by their different diets: $C$. edule is a suspension feeder while M. balthica is a facultative deposit feeder (Riera et al., 1999; Rossi et al., 2004) so their diets are not based on the same proportions of POM, SOM and MPB. Hydrobia ulvae, a grazer gastropod that mainly feeds on seagrass and benthic diatoms, had an enriched carbon signature compared to the microphytobenthos. Nepthys hombergii, a carnivorous polychaete, had a higher isotopic nitrogen signature than the other benthic invertebrates. The other carnivorous invertebrate, the shrimp Crangon crangon, had $\mathrm{C}$ and $\mathrm{N}$ isotopic values very close to YoY Solea solea. These three carnivorous species occupy the highest trophic positions among the species sampled in the nursery ground. Based on these marked signatures, the main sources contributing to the energy flow towards the YoY sole originate in organic matter both from the water column and the sediment.

Finally, in the Vilaine estuary, the benthic food web structure (including YoY sole) depicted by stable isotopes is relatively similar to other case studies of the Tagus estuary (Portugal, Vinagre et al. (2008), the Gulf of Lions (France, Darnaude et al., 2004) and the Thames estuary (UK, Leakey et al., 2008). Solea solea occupied the highest trophic position among the species sampled in the nursery ground. Moreover, estuarine effect has been underlined by following terrestrial organic matter incorporation in benthic food web, from invertebrates to juvenile common sole. 


\subsection{Spatio-temporal variations in the trophic signature in relation to the river flow}

To determine these spatio-temporal variations we focused on the dynamic of the $\delta^{13} \mathrm{C}$ and $\delta^{15} \mathrm{~N}$ inner and outer the Vilaine estuary, paying particular attention to interannual fluctuations in river discharge. Nursery ground trophic structures in July were very similar in wet and dry years. No difference in the relative isotopic gradients was detected in the food web (no difference in interspecies gradients between years), although the wet years were more $\delta^{13} \mathrm{C}$ depleted than the dry years. The POM carbon signature, which depends on the frequency and intensity of the rains and consecutive river inputs (Malet et al., 2008), was quite variable over the years, no doubt because more terrestrial carbon comes into the estuary in wet years than in dry years. Statistical differences in the carbon signatures of areas A and B were also noticed between rainy (depleted) and dry (enriched) years. These spatio-temporal differences were verified for organic matter, some of the benthic invertebrates and YoY sole. For this reason, it appeared that varying river inputs over the years lead to differences in the POM carbon signatures that propagated throughout the entire benthic food web up to YoY sole in Vilaine estuary, with a downstream range depending on the intensity of the river flow.

This suggests a close relationship between benthic food webs and river input: during dry years (2004 and 2005), the terrestrial carbon signature was only found near the dam at the mouth of the Vilaine estuary, while this signature was also found in marine waters during rainy years (2007 and 2008). The Vilaine benthic food web shifted from a network with a mix of terrestrial and marine influences during dry years to an higher terrestrial influence when river flow is high. Yokoyama and Ishihi (2007) and Choy et al. (2008) have already used stable isotope to demonstrate a variation in the food sources of benthic macroinvertebrates along a land-sea transect. The present study confirms these results and provides two other pieces of information: the terrestrial influence differs in intensity and spatial extent from one year to another, with relation to river inputs, and it is propagated up to juvenile flatfish through their trophic interactions.

\subsection{Estuarine dependence and determinism in sole recruitment}

Benthic invertebrates constitute the food supply for young fish in nursery grounds (Howell et al., 1999; McConnaughey and Smith, 2000; Phelan et al., 2001). For the Vilaine and Loire (an adjacent river) estuaries, Marchand and Masson (1989) and Marchand (1993) have shown the impact of salinity and turbidity on the settling of the benthic communities (dominated by young polychaetes and bivalves) preyed upon by euryhaline fishes, especially the common sole. The development of communities that tolerate low salinity levels provides suitable food for young sole (Costa and Bruxelas, 1989), thus also providing an energetic benefit of feeding in the estuary (Leakey et al., 2008). Darnaude et al. (2004) concluded that high land-based run-off was favourable for the productivity of invertebrate prey, and thus for the juvenile common sole in the Mediterranean.

The present study confirms the estuarine opportunism of YoY sole and highlights the interannual variability of the river influence on estuarine nursery grounds, in terms of the river flow. The link between the amount of freshwater input and the spatial range of the nursery ground under estuarine influence has previously been demonstrated both for YoY density and spatial distribution (Le Pape et al., 2003c). The present study adds a trophic dimension to this statistical relationship: the estuarine based trophic chain and its spatio-temporal dynamics could at least partially explain the positive influence of river flow on sole recruitment in the Vilaine estuary and the adjacent Bay (Le Pape et al; 2003 bc), but also more generally in the Bay of Biscay at the level of population (Le Pape et al; 2003 ac). Similarly, Dolbeth et al. (2008) have emphasized drought as a probable key reason for the decreased production of marine juvenile species in estuaries.

The ability of benthic fish to exploit terrestrial POM inputs depends on their ecology (Darnaude, 2005; Leakey et al., 2008), and fish assemblages show a trend towards the enrichment of their carbon isotopic signatures from the upper towards the lower estuary (Pasquaud et al., 2008). 
Hence, these results on the common sole must be considered as specific, in terms of the life cycle of this species and its relative estuarine opportunism (Araujo et al., 2000; Le Pape et al., 2003ab). Nevertheless, these results about juvenile sole estuarine dependence can also be considered more generally, focusing on the important role played by estuaries as essential fish habitats. Estuaries play a determining role for marine fish population renewal (Beck et al., 2001; Peterson, 2003), especially through the trophic link related to high productivity.

This dependence must be assessed to analyse the consequences of river discharge variations on marine fish populations and related fisheries (Darnaude, 2005). The consequences of lower river inputs linked to anthropogenic uptake of freshwater and climate changes could be harmful (Chicharo et al., 2006; Dolbeth et al., 2008). This could be particularly true if trophic enrichment of the marine fish food chain by terrestrial-derived subsidies is altered during the growth period of fish in estuarine nursery grounds.

\section{Acknowledgements}

This project was supported by the French National Programme for Coastal Environment (PNEC) and by the French National Research Agency (ANR, Projects SoleBeMol-Pop, ANR Vulnérabilité, Milieux et climat, and project Amphore, ANR biodiversité). Special thanks to Yves Désaunay, Jean-Paul Bourse and Jean-Pierre Nöel for their help with the field analyses. The authors are also grateful to Lisa Ellen Spencer for editing their English and to the two anonymous reviewers for their helpful advices. 


\section{References}

Araujo, F.G., Williams, W.P., and Bailey, R.G., 2000. Fish assemblages as indicators of water quality in the middle Thames estuary, England (1980-1989). Estuaries 23, 305-317.

Beck, M., Heck, K., Able, K., Childers, D., Eggleston, D., Gillanders, B.M., Halpern, B., Hays, C., Hostino, K., Minello, T.J., Orth, R., Sheridan, P., Weinstein, M.P., 2001. The role of nearshore ecosystems as fish and shellfish nurseries. Bioscience 51, 633-641.

Bodin, N., Le Loc'h, F. and Hily, C., 2007. Effects of lipid removal on carbon and nitrogen stable isotope ratios in crustacean tissues. Journal of Experimental Marine Biology and Ecology, 341: 168-175.

Bouillon, S., Mohan, P.C., Sreenivas, N., Dehairs, F., 2000. Sources of suspended organic matter and selective feeding by zooplankton in an estuarine mangrove ecosystem as traced by stable isotopes. Marine Ecology Progress Series 208, 79-92.

Chícharo, M. A., Chícharo, L. and Morais, P., 2006. Inter-annual differences of ichthyofauna structure of the Guadiana estuary and adjacent coastal area (SE Portugal/SW Spain): before and after Alqueva dam construction. Estuarine, Coastal and Shelf Science, 70 (1-2): 39-51.

Choy, E.J., An, S., and Kang, C.K., 2008. Pathways of organic matter through food webs of diverse habitats in regulated Nakdong river estuary (Korea). Estuarine, Coastal and Shelf Science 78, 215-226.

Costa, M. J. and Bruxelas, A., 1989. The structure of fish communities in the Tagus Estuary, portugal and its role as nursery for commercial fish species. Scientia Marina Topics in Marine biology, Ros, J.D. ed, 53, 561-566.

Darnaude, A.M., Salen-Picard, C., Polunin, N.V.C., Harmelin-Vivien, M.L., 2004. Trophodynamic linkage between river runoff and coastal fishery yield elucidated by stable isotope data in the Gulf of Lions (NW Mediterranean). Oecology 138, 325-332.

Darnaude, A.M., 2005. Fish ecology and terrestrial carbon use in coastal areas: implications for marine fish production. Journal of Animal Ecology 74, 864-876.

DeNiro, M.J. and Epstein, S. 1981. Isotopic composition of cellulose from aquatic organism. Geochimica et Cosmochimica Acta 42, 495-506.

Dolbeth, M, Martinho, F, Viegas, I, Cabral, H, and Pardal, MA., 2008. Estuarine production of resident and nursery fish species: conditioning by drought events. Estuarine, Coastal and Shelf Science 78, 51-60.

Dorel, D., Koutsikopoulos, C., Desaunay, Y., Marchand, J., 1991. Seasonal distribution of young sole (Solea solea (L.)) in the nursery ground of the Bay of Vilaine (Northern Bay of Biscay). Netherlands Journal of Sea Research 27, 297-306.

Fry, B., 2006. Stable isotope ecology. Springer Science+BusinessMedia LLC, New York, 308 pp.

Gaston, T.F., Kostoglidis, A., Suthers, I.M., 2004. The C-13, N-15 and S-34 signatures of a rocky reef planktivorous fish indicate different coastal discharges of sewage. Marine and Freshwater Research 55, 689-699. 
Gibson, R.N., 1994. Impact of habitat quality and quantity on recruitment of juvenile flatfishes. Netherlands Journal of Sea Research, 32, 191-206.

Guelinckx, J., Maes, J., Geysen, B. and Ollevier, F., 2008. Estuarine recruitment of a marine goby reconstructed with an isotopic clock. Oecologia, 157(1): 41-52

Hesslein R.H., Hallard K.A. and Ramlal, P. 1993. Replacement of sulfur, carbon, and nitrogen in tissue of growing broad Whitefish (Coregonus nasus) in response to a change in diet traced by d34S, d13C, and d15N. Canadian Journal of Fisheries and Aquatic Sciences., 50: 2071-2076.

Howell, P. T., Molnar, D. R., and Harris, R. B., 1999. Juvenile winter flounder distribution by habitat type. Estuaries 22, 1090-1095.

Johnson, L. L., Landhal, J.T., Kubin, L.A., Horness, B.H., Myers, M.S., Collier, T.K., Stein, J.E., 1998. Assessing the effects of anthropogenic stressors on Puget Sound flatfish populations. Journal of Sea Research 39, 125-137.

Kharlmamenko, V.I., Kiyashko, S.I., Imbs, A.B. and Vyshkvartev, D.I., 2001. Identification of food sources of invertebrates from the seegrass Zostera marina community using carbon and sulfur stable isotope ratio and fatty acid analyses. Marine Ecology Progress Series, 220: 103117.

Kimmerer, W. J., 2002. Effects of freshwater flow on abundance of estuarine organisms: physical effects or trophic linkages? Marine Ecology Progress Series 243, 39-55.

Koutsikopoulos, C., Desaunay, Y., Dorel, D., and Marchand, J. 1989. The role of coastal areas in the life history of sole (Solea solea L.) in the Bay of Biscay. Scientia Marina 53, 567-575.

Le Loc'h, F and Hily, C., 2005. Stable carbon and nitrogen isotopes analysis of Nephrops norvegicus/Merluccius merluccius fishing grounds in the bay of Biscay (North East Atlantic). Canadian Journal of Fisheries and Aquatic Sciences 62(1), 123-132.

Le Pape O., Holley J., Guérault D., Désaunay Y. 2003, a. Quality of coastal and estuarine essential fish habitat: estimations based on the size of juvenile common sole (Solea solea L.). Estuarine, Coastal and Shelf Science, 58, 793-803.

Le Pape O., Chauvet F., Mahévas S., Lazure L., Guérault G., Désaunay Y. 2003, b. Quantitative description of habitat suitability for the juvenile common sole (Solea solea, L.) and contribution of different habitats to the adult population in the Bay of Biscay (France). Journal of Sea Research, 50 (2-3), 139-149.

Le Pape O., Chauvet F., Desaunay Y., Guerault G. 2003, c. Relationship between interannual variations of the river plume and the extent of nursery grounds for the common sole (Solea solea, L.) in Vilaine Bay. Effects on recruitment variability. Journal of Sea Research, 50 (2/3), 177-185.

Le Pape O., Desaunay Y., Guerault D. 2003, d. Relationship between fluvial discharge and sole (Solea solea, L.) recruitment in the Bay of Biscay (France). Study of an estuarine nursery ground and application on a stock scale. ICES Marine Science Symposia, 219, 241-248.

Le Pape O., Baulier L., Cloarec A., Martin J., Le Loc'h F. and Y. Désaunay, 2007. Habitat suitability for the juvenile common sole (Solea solea, L.) in the Bay of Biscay (France): a quantitative description using indicators based on benthic fauna. Journal of Sea Research 57: 126-136. 
Leakey, C.D.B., Attrill, M.J., Jennings, S. and Fitzsimons, M.F., 2008. Stable isotopes in juvenile marine fishes and their invertebrate prey from the Thames Estuary, UK, and adjacent coastal regions. Estuarine, Coastal and Shelf Science, 77(3): 513-522.

MacAvoy, S.E., Macko, S.A. and Garman, G. 2001. Isotopic turnover in aquatic predators: quantifying the exploitation of migratory prey. Canadian Journal of Fisheries and Aquatic Sciences, 58 (5):923-932.

Malet, N., Sauriau, P.G., Ryckaert, M., Malestroit, P. and Guiljou, G., 2008. Dynamics and sources of suspended particulate organic matter in the Marennes-Oleron oyster farming bay: Insights from stable isotopes and microalgae ecology. Estuarine, Coastal and Shelf Science, 78(3): 576-586.

Marchand, J., 1991. The influence of environmental conditions on settlement distribution and growth of 0-group sole (Solea solea (L.)) in a macrotidal estuary (Vilaine, France). Netherlands Journal of Sea Research 27, 307-316.

Marchand J., 1993. The influence of seasonal salinity and turbidity maximum variations on the nursery function of the Loire estuary (France). Netherlands Journal of Aquatic Ecology 27(2-4), 427-436.

Marchand, J. and Masson, G., 1989. Process of estuarine colonization by 0-groupsole (Solea solea): hydrological conditions, behaviour and feeding activity in the Vilaine estuary. Rapport P.V. Réu. CIEM 191, 287-295.

Mc Connaughey, R. A. and Smith, K. R., 2000. Associations between flatfish abundance and surficial sediments in the eastern Bering Sea. Canadian Journal of Fisheries and Aquatic Sciences 57, 2410-2419.

Minagawa, M. and Wada, E., 1984. Stepwise enrichment of ${ }^{15} \mathrm{~N}$ along food chains: further evidence and the relation between $\delta^{15} \mathrm{~N}$ and animal age. Geochimica et Cosmochimica Acta, 48, 1135-1140.

Nicolas, D., Le Loc'h, F., Désaunay, Y., Hamon, D., Blanchet, A., Le Pape, O. 2007. Relationships between benthic macrofauna and habitat sustability for juvenile common sole (Solea solea) in the Vilaine estuary (Bay of Biscay, France) nursery ground. Estuarine and Coastal Marine Science, 73, 639-650.

O'Reilly, C.M., Hecky, R.E., Cohen, A.S. and Plisnier, P.-D., 2002. Interpreting stable isotopes in food web: Recognizing the role of time averaging at different trophic levels. Limnology and Oceanography, 47(1): 306-309.

Pasquaud, S., Elie, P., Jeantet, C., Billy, I., Martinez, P., and Girardin, M. 2008. A preliminary investigation of the fish food web in the Gironde estuary, France, using dietary and stable isotope analyses. Estuarine, Coastal and Shelf Science 78, 267-279.

Peterson, B.J., Howarth, R.W., Garrit, R.H., 1985. Multiple stable isotopes used to trace the flow of organic matter in estuarine food webs. Science 227, 1361-1363.

Peterson, B.J., Fry, B., 1987. Stable isotopes in ecosystem studies. Annual Review of Ecology and Systematics 18, 293-320.

Peterson, C. H., Summerson, H.C., Thomson, E., Lenihen, H.S., Grabowski, J., Manning, L., Micheli, F., Johnson, G., 2000. Synthesis of linkages between benthic and fish communities as key to ptrotecting essential fish habitat. Bulletin of Marine science 66, 759-774. 
Peterson, M. 2003. A conceptual view of environment-habitat-production linkages in tidal river estuaries. Reviews in Fisheries science 11(4), 291-313.

Phelan, B. A., Manderson, J.P., Stoner, A.W., Bejda, A.J., 2001. Size-related shifts in the habitat associations of young-of-the-year winter flounder (Pseudopleuronectes americanus): field observations and laboratory experiments with sediments and prey. Journal of Experimental Marine Biology and Ecology 257, 297-315.

Pinnegar, J.K., Polunin, N.V.C., 1999. Differential fractionation of $\delta^{13} \mathrm{C}$ and $\delta^{15} \mathrm{~N}$ among fish tissues: implications for the study of trophic interactions. Functional Ecology 13, 225-231.

Quiñones, R. A. and Montes, R. M., 2001. Relationship between freshwater input to the coastal zone and the historical landings of the benthic/demersal fish Eleginops maclovinus in centralsouth Chile. Fisheries Oceanography 10, 311-328.

Riera, P., Richard, P., 1996. Isotopic determination of food sources of Crassostrea gigas along a trophic gradient in the estuarine bay of Marennes-Oléron. Estuarine, Coastal and Shelf Science $42,347-360$.

Riera, P., Stal, L.J., Nieuwenhuize, J., Richard, P., Blanchard, G., Gentil, F., 1999. Determination of food sources for benthic invertebrates in a salt marsh (Aiguillon Bay, France) by carbon and nitrogen stable isotopes: importance of locally produced sources. Marine Ecology Progress Series 187, 301-307.

Rijnsdorp, A. D., Van Beek, F.A., Flatman, S., Milner, R.M., Riley, R.D., Ginet, M., De Clerk, R., 1992. Recruitment of sole stocks, Solea solea (L.), in the northeast Atlantic. Netherlands Journal of Sea Research 29, 173-192.

Rossi, F., Herman, P.M.J. and Middelburg, J.J. 2004. Interspecific and intraspecific variation of $\mathrm{d} 13 \mathrm{C}$ and $\mathrm{d} 15 \mathrm{~N}$ in deposit- and suspension feeding bivalves (Macoma balthica and Cerastoderma edule): Evidence of ontogenetic changes in feeding mode of Macoma balthica. Limnololy and Oceanography, 49(2), 408-414.

Rowell, K, Flessa, KW, Dettman, DL, and Roman, M., 2005. The importance of colorado river flow to nursery habitats of the Gulf curvina (Cynoscion othonopterus). Canadian journal of fisheries and aquatic sciences 62(12), 2874-2885.

Rubec, P. J., Bexley, J.C.W., Norris, H., Coyne, M.S., Monaco, M.E., Smith, S.G., Ault, J.S., 1999. Suitability modelling to delineate habitat essential to sustainable fisheries. American Fisheries Society Symposium 22, 108-133.

Salen-Picard, C. and Arlhac, D., 2002. Long-term changes in a Mediterranean benthic community: relationships between the polychaete assemblages and hydrological variations of the Rhône river. Estuaries, 25, 1121-1130.

Salen-Picard, C., Darnaude, A.M., Arlhac, D. and Harmelin-Vivien, M.L., 2002. Fluctuations of macrobenthic populations: a link between climate-driven river run-off and sole fishery yields in the Gulf of Lions. Oecologia, 133, 380-388.

Staunton-Smith, J., Robins, J. B., Mayer, D. G., and Sellin, M. J. Hallyday I. A., 2004. Does the quantity and timing of fresh water flowing into dry tropical estuary affect year-class strength of barramundi (Lates calcarifer)? Marine and Freshwater Research. 55(8), 787-797. 
Sweeting, C.J., Barry, J., Barnes, C., Polumin, N.V.C. and Jennings, S., 2007. Effects of body size and environment on diet-tissue $\delta^{15} \mathrm{~N}$ fractionation in fishes. Journal of Experimental Marine Biology and Ecology, 340: 1-10.

van der Veer, H.W., Bergham, R., Miller, J.M., Rijnsdorp, A.D., 2000. Recruitment in flatfish, with special emphasis on North Atlantic species: Progress made by the Flatfish Symposia. Ices Journal of Marine Science 57, 202-215.

Vander Zanden, M.J. and Rasmussen, J.B., 2001. Variation in $\delta^{15} \mathrm{~N}$ and $\delta^{13} \mathrm{C}$ trophic fractionation: implications for aquatic food web studies. Limnology and Oceanography, 46, 2061-2066.

Vinagre, C, Salgado, J, Costa, MJ, and Cabral, HN., 2008. Nursery fidelity, food web interactions and primary sources of nutrition of the juveniles of Solea solea and S. Senegalensis in the Tagus estuary (Portugal): a stable isotope approach. Estuarine, Coastal and Shelf Science $76,255-264$.

Winemiller, K.O. , Akin S, and Zeug SC., 2007. Production source and food web structure of a temperate tidal estuary: integration of dietary and stable isotope data. Marine Ecology Progress Series 343, 63-76.

Yokoyama, H. and Ishihi, Y., 2007. Variation in food sources of the macrobenthos along a landsea transect: a stable isotope study. Marine Ecology Progress Series 346, 127-141.

Zeug, S.C. and Winemiller, K.O. 2008. Evidence supporting the importance of terrestrial carbon in a large river food web. Ecology 89(6), 1733-1743. 


\section{Figures}

Figure 1

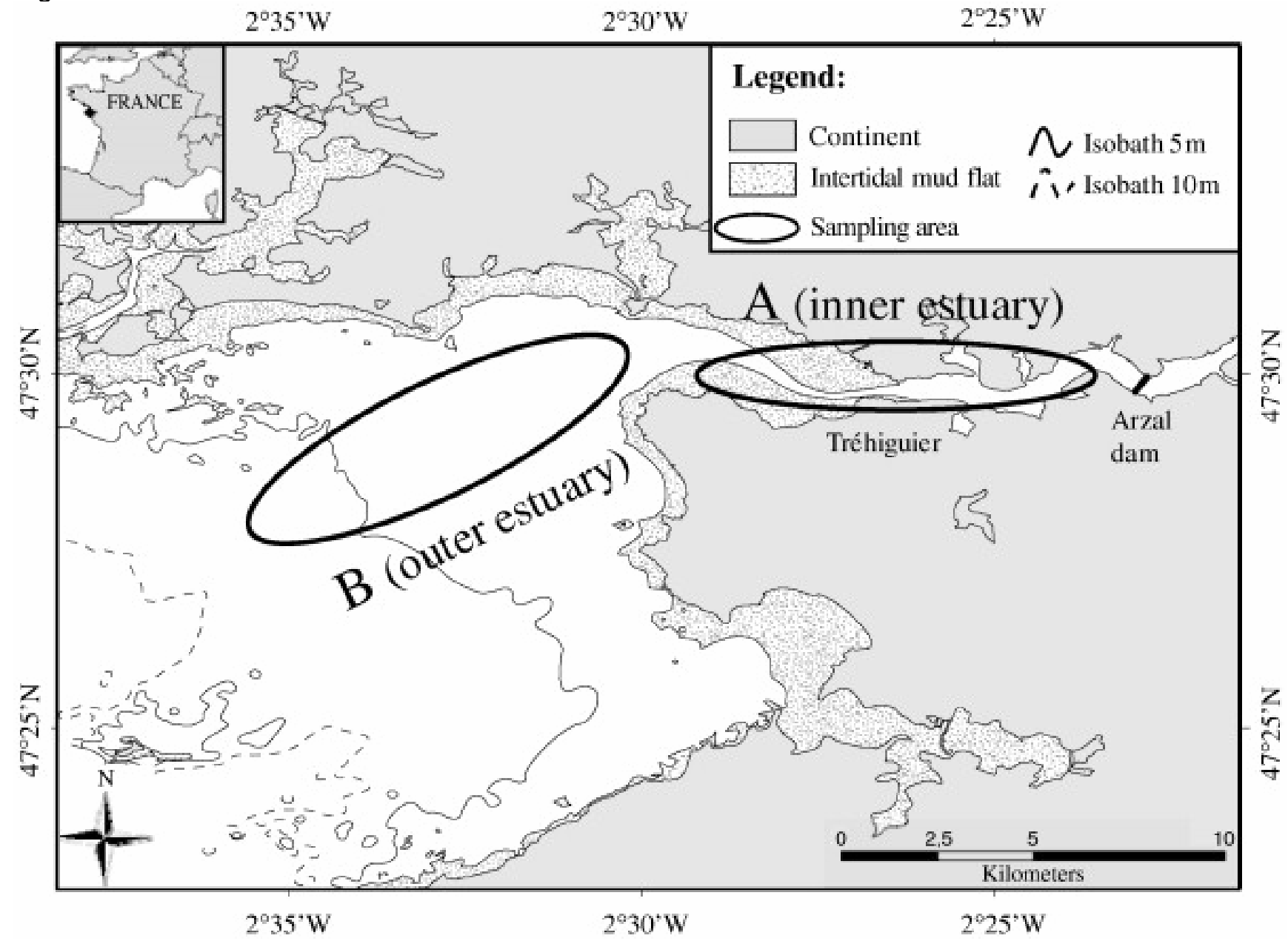

Fig. 1: Vilaine estuary and location of the sampling areas A and B. In the upper left corner of the figure: general location of the study area in France 
Figure 2

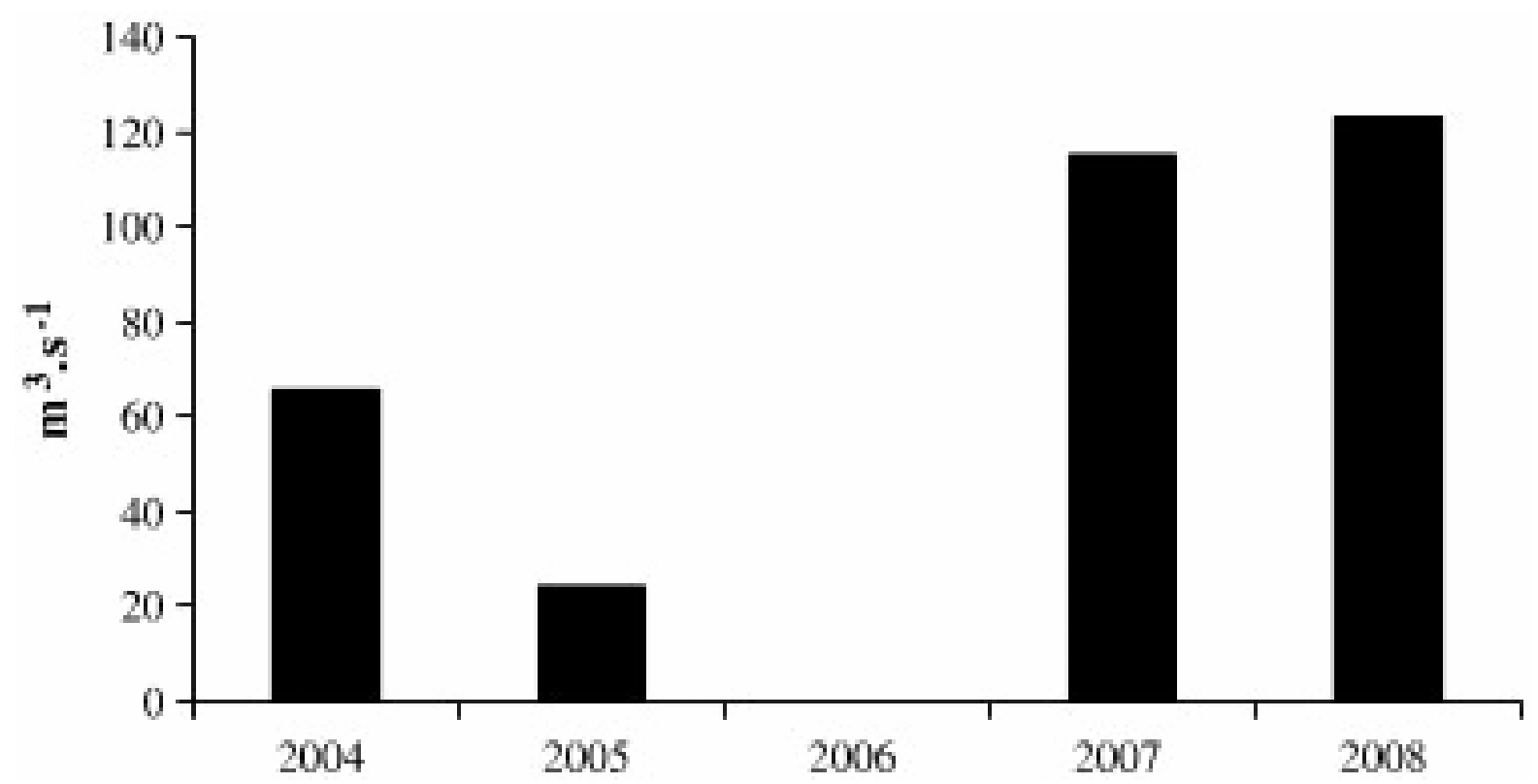

Fig. 2: Mean Vilaine river flow calculated from February to June at Arzal dam (in $\mathrm{m}^{3} . \mathrm{s}^{-1}$ ) 
Figure 3

Fig. 3: Mean ( \pm Standard Deviation) $\delta^{13} \mathrm{C}$ and ${ }^{\delta 15} \mathrm{~N}$ values in area $\mathrm{A}$ in 2005 (a) and 2007 (b) for carbon and nitrogen sources [particulate organic matter from freshwater (POM fw) and from area A (POM); sediment organic matter (SOM) and microphytobenthos (MPB)], benthic invertebrates [Macoma balthica (Mac), Cerastoderma edule (Cer), Hydrobia ulvae (Hyd), Nephtys hombergii (Nep), Crangon crangon (Cra)] and young of the year common sole (Sole)
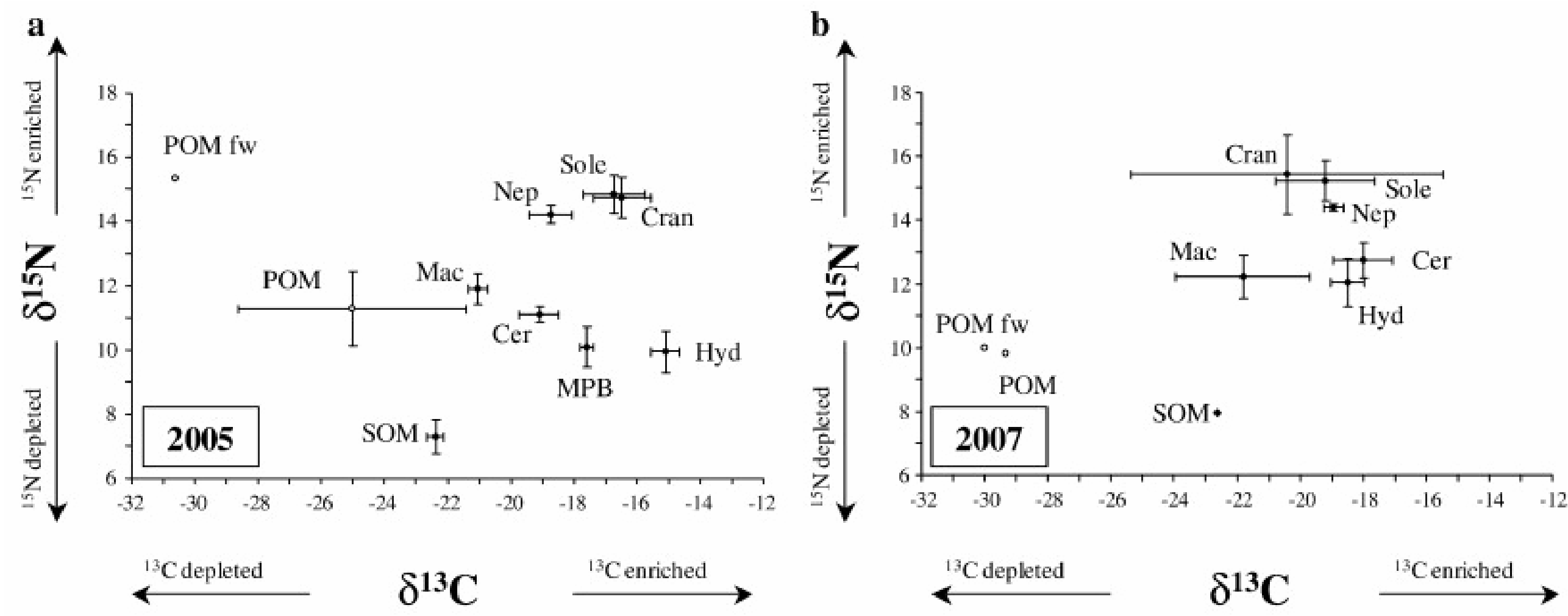
Figure 4

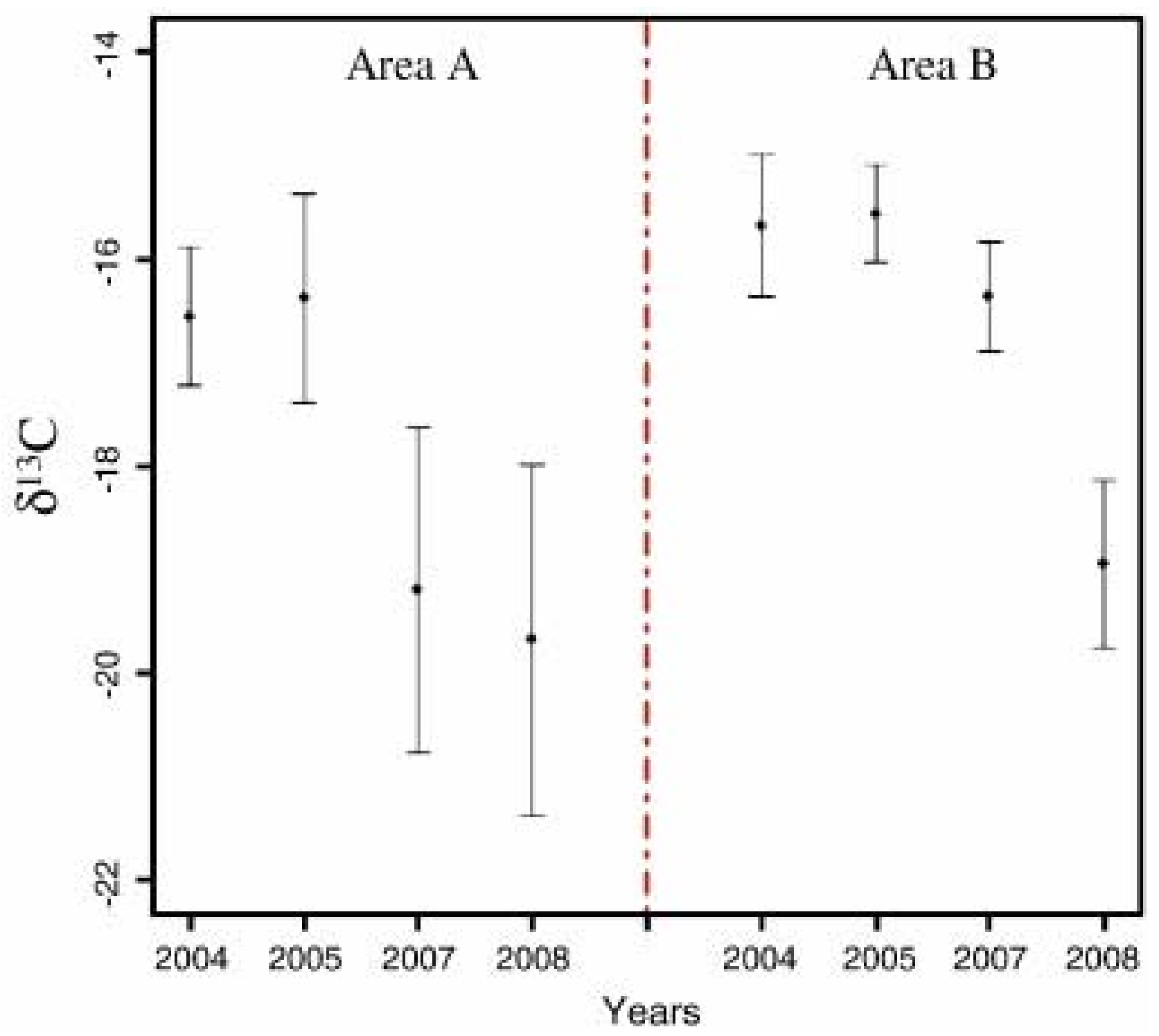

Fig. 4: Mean ( \pm Standard Deviation) stable carbon isotope values for young of the year sole in each area (A and B) for all years (2004, 2005, 2007 and 2008) 


\section{Tables}

Table 1: Number of samples (Solea solea, invertebrates and organic matter: POM (Particulate Organic Matter), SOM (Sediment Organic Matter) and MPB (Microphytobenthos)) used in this study for each area and each year

\section{AREA A}

\section{AREA B}

$2004 \quad$ Solea solea: 9 individuals Invertebrates: 23 individuals

Organic matter: 0 sample
Solea solea: 15 individuals

Invertebrates: 15 individuals

Organic matter: 0 sample
2005

Solea solea: 18 individuals

Invertebrates: 35 individuals

Organic matter: 12 samples (6 POM + 3 SOM + 3 MPB)
Solea solea: 6 individuals

Invertebrates: 4 individuals

Organic matter: 3 samples (3 POM + 0 SOM)
2007

Solea solea: 5 individuals

Invertebrates: 39 individuals

Organic matter: 4 samples (2 POM + 2 SOM)
Solea solea: 12 individuals

Invertebrates: 32 individuals

Organic matter: 3 samples (2 POM + 1 SOM)
2008
Solea solea: 24 individuals Invertebrates: 39 individuals

Organic matter: 10 samples (8 POM + 2 SOM)

\section{Solea solea: 5 individuals}

Invertebrates: 9 individuals

Organic matter: 4 samples (3 POM + 1 SOM) 
Table 2: Tukey test on the stable carbon isotope values for YoY sole between areas

4.1. Area A / AREa B

$20040.008^{* \star}$

$2005 \quad 0.105$

$2007<10^{-4}$ ***

$2008 \quad 0.358$

All years

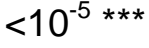

${ }^{*} p<0.05,{ }^{* *} p<0.01,{ }^{* * *} p<0.001$ 
Table 3: Tukey test on the stable carbon isotope values for YoY sole between years

5. a) 6 .

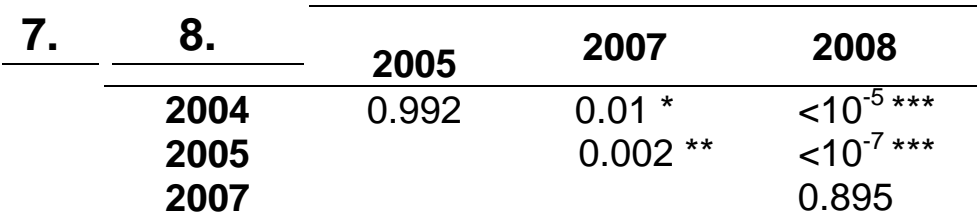

${ }^{\star} p<0.05,{ }^{* *} p<0.01,{ }^{* * *} p<0.001$ b) 6.2

6.3. AREA B

\begin{tabular}{llll} 
& 2005 & 2007 & 2008 \\
\hline 2004 & 0.986 & $0.044^{*}$ & $<10^{-7 \star \star \star}$ \\
2005 & & 0.103 & $<10^{-7} \star \star \star$ \\
2007 & & & $<10^{-6 \star \star \star}$
\end{tabular}

